\title{
Applications to discrete Morse theory: The collapsibility of CAT(0) cubical complexes of dimension 2 and 3
}

\author{
IOANA-CLAUDIA LAZĂR
}

\section{ABSTRACT.}

We investigate, using discrete Morse theory, the collapsibility of finite cubical complexes of dimension 2 and 3 . Our main result states that any finite cubical complex of dimension 3 or less endowed with the standard piecewise Euclidean metric that is non-positively curved, and that satisfies the property that every 2-cell is the face of at most two 3-cells in the complex, collapses to a point.

\author{
"BABEŞ-BOLYAI" UNIVERSITY \\ DEPARTMENT OF GEOMETRY \\ M. KOGĂLNICEANU 1 \\ 400084 CLUJ-NAPOCA, ROMANIA \\ E-mail address: lioana@math.ubbcluj.ro
}

Received: 12.09.2010; In revised form: 20.05.2011; Accepted: 30.06.2011 